\title{
https://doi.org/10.46344/JBINO.2020.v09i5b.14
}

\section{REVIEW OF GARA VISHA AYURVEDA TOXICOLOGY}

\author{
Dr. Dnyaneshwar Sonba Naykodi \\ Associate Professor Agadtantra Deptt. Ashvin Rural Ayurved College,Manchihill \\ (Received on Date: $27^{\text {th }}$ July 2020 \\ Date of Acceptance: $11^{\text {th }}$ August 2020 Date of Publish: 24 $4^{\text {th }}$ September 2020) \\ Email: drnaykodids@gmail.com
}

\begin{abstract}
Human body has the natural tendency to defend itself by eliciting immune response for the maintenance of health. Immune response is recognizing and destroying the antigens of microorganism by triggering the innate immune components such as activation of T-cell or production of antibodies. Sometimes in the sensitive individuals antigens present in the environment produces altered immune response called hypersensitivity. It is manifested with signs and symptoms that are at times lethal. Hapten-carrier adduct behaves as an allergen and induces hypersensitive reactions. Hapten is a small molecule which combines with a large protein, forming hapten-carrier adduct and evokes immune response. Signs and symptoms often with detrimental effect are also found when the body is afflicted with Garavisha
\end{abstract}

Keywords: Ayurveda, Gara Visha, Antibodies. 


\section{INTRODUCTION}

Karl Landsteiner is the pioneer of the concept of hapten. Haptens are small molecules $(<1000$ D) that combine with large protein to form hapten-carrier adduct. Hapten alone cannot elicit immune response; even the carrier protein by itself may not produce the same. The hapten-protein combination is the haptencarrier adduct that acts as antigen and binds with specific antibodies or activated T-cell to produce immune reaction. Hapten-carrier adduct some time acts as allergen and their exposure primarily occurs through skin surface, oral route, and respiratory tract. The dietary hapten exposure through processed food and formula milk is common nowadays. [3] Notable example of hapten is urushiol which is absorbed through the skin and undergoes oxidation to produce a reactive molecule quinone (the actual hapten). Quinone reacts with skin protein to form hapten-carrier adduct which acts as toxin. The first exposure of the body to the hapten-carrier adduct causes sensitization and proliferation of the effect or T-cell, while in the subsequent exposure, the activated T-cell generates immune reaction by producing skin blisters.[4]

\section{Concept of hypersensitivity}

Under normal circumstances, host defense in proper progressive order culminates in well-controlled immune and inflammatory response that protects him/her from offending antigens. The immune response in some person appears as side effect called hypersensitivity.[5] Hypersensitivity is a symptomatic interaction between host defense and allergen causing exaggerated and harmful response in the body. Hypersensitivity is frequently known as allergy and reaction ranges from mild to life-threatening. It is mainly of two types, immediate hypersensitivity and delayed hypersensitivity.[6] In immediate hypersensitivity reactions, there is immediate manifestation of symptoms and is mediated by IgE antibody. The antigen binds to IgE antibodies already attached to the mast cell because of previous exposure to the same antigen. The antigen-antibody reaction releases plenty of histamine and other chemicals from mast cell causing vasodilatation and shock along with other symptoms. Delayed hypersensitivity reaction is mediated by $T_{H} 1$ helper $T$-cells $\left(T_{4}\right.$ cell). The reaction results in delayed symptoms. In the first exposure, allergen processed by the macrophage is presented to $\mathrm{T}_{4}$ cell for its activation. In the second exposure, more activated $\mathrm{T}_{4}$ cells are formed. $\mathrm{T}_{4}$ cell secretes many chemicals causing activation of more macrophages that destroy the allergen and at the same time, there are indurations, redness and destruction of healthy tissues in that area. Antigen in the form of allergen introduced for the first time in life in host body is the sensitizing dose and reaction does not occur, but on second exposure, reactions appear.

In the traditional Gell and Coombs system of classification, hypersensitivity reactions are of four types:[]] 
- Type I hypersensitivity reaction is IgE antibody reaction. Atopic allergy with genetic predisposition belongs to this category

- Type II hypersensitivity reaction is cyto-toxic reaction

- Type III hypersensitivity reaction is immunocomplex reaction

- Type IV hypersensitivity reaction is delayed reaction mediated by helper T-cell.

The former classification of two types of hypersensitivity reaction (immediate and delayed) is relevant for the present article.

\section{The concept of Visha}

The word Visha is derived from the root "Vis"by having "Ka"preposition. This means to encompass, pervade, or occupy. The term Visha gets its name fromVishada. Substance that enters and vitiates the healthy Dhatu (structural components, tissues) of the body and may or may not manifest with lethal signs and symptoms is termed as Visha.[8]

Ayurveda describes three varieties of Visha, i.e., Jangama (animal origin), Sthavara (plant and mineral origin) and Kritrima (artificial poison).[9]

The third variety of poison is prepared by the combination of different materials. When it is produced by the combination of two nonpoisonous materials, it is called Garavisha; while combination of two poisonous materials forms Kritrima Visha.[10]
The concept of Garavisha

The word Gara is derived from root word "Gri" with the suffix "Ac." This means diluted or reduced in potencies.[11]Garavisha is a combination of two nonpoisonous substances. It slowly produces toxic effect by vitiating the Dhatu (structural components of the body). This is followed by manifestation of mild to drastic clinical features. Unlike other poison, it does not cause instantaneous death. Garavisha commonly enters the body through food preparations.[12] By nonpoisonous, it means that each ingredient forming Garavisha when enters the body separately does not produce any symptom, but their combination has poisonous effect producing adverse clinical features such as laziness, heaviness of the body, cough, dyspnea and edema that appear after 15 days or 1 month duration of affliction.[13] There are ten attributes of Visha.[14] These are equally applicable for Garavisha but are of Alpa Virya (mild intensities).

Garavisha is a combination of two nonpoisonous components (substances) producing signs and symptoms of Visha after application or consumption. Hapten-carrier adduct is also a combination of two components, hapten and carrier protein. As a single component hapten or carrier protein does not function as immunogen and cannot elicit immune response.

Single component of Garavisha also does not produce Visha (toxic) effect. They produce toxic effects on combination. The combining 
forming Garavisha may be of Viruddha Veerya (mutually contradictory potencies) obtained from Viruddha Ahara and other sources of Viruddha. The resultant reaction of two mutually contradictory potencies is adverse for the body and hence, Garavisha is a toxin and behaves as an allergen. The hapten and the carrier protein do not produce immunogenic effect separately, but their combination as hapten-carrier adduct makes them bind to the antigen presenting cell for activation of T- and B-cells and produce harmful immune reaction. Hence, Garavisha has a striking similarity with the hapten-carrier adduct.

Garavishalike other varieties of Visha causes Vishada or stressful condition. It is of slow reacting nature and gradually produces toxic effect by vitiating Dhatu through formation of Amadosha and Agnimandya, while exposure to hapten-carrier adduct causes sensitization and proliferation of the effector T-cells and antibodi es present in the body, and on subsequent exposure, sometimes, stressful immune response is triggered at the site (tissues) of sensitization by activated memory T-cell and antibodies. The stressful immune response is the adverse effect of body's defensive mechanism and is called hypersensitivity. The reaction of Garavisha is likely comparable to hypersensitive response to body's immune mechanism.

In immediate hypersensitivity reaction, response is seen within $12 \mathrm{~h}$ of antigen challenge to preformed antibodies. Atopic allergy with genetic predisposition (allergy running in the family) produces immediate hypersensitive response with symptoms manifesting within few minutes to few hours. Symptoms appear after 2-4 weeks due to Garavisha affliction. In Ayurvedic treaties, Garavisha poisoning is not included under Kulaja Vyadhi. Immediate hypersensitivity reaction along with atopic allergy does not match with the characteristic result of Garavisha and so cannot be included under its ambit.

Kalantara Vipaka[28] implies delayed reaction of Garavisha. It takes time for such poison to get metabolized and produce toxic effect. This feature is common to delayed hypersensitivity reaction that takes few days to week for the development of symptoms. Garavisha is analogues to hapten-carrier adduct that can produce delayed hypersensitivity.

The concept of hapten-carrier adducts and delayed reaction hypersensitivity existed in the Ayurvedic treaties centuries ago and the terms Garavisha was applied for it. Clinically, hapten-carrier adduct and Garavisha produce more or less same type of clinical manifestation and systemic involvement. This aroused the necessity to relate Garavisha with hapten-carrier adduct. Further comprehensive and analytical studies are necessary to establish the concept of Garavisha with hapten and hapten-carrier adduct which may open new dimensions to understand the concept of Garavisha.

\section{REFERENCES}

Haynes BF, Fauci AS. Disorders of the immune system. Harrison's Principles of Internal Medicine. In: Eugene Braunwald, 2020 September Special Issue Edition | www.jbino.com | Innovative Association 
Anthony S. Fauci, Dennis L. Kasper, Stephen L. Hauser, Dan L. Longo, J. Larry Jameson, editors. 15th ed. USA: The McGraw-Hill; 2001.pp. 1805-1825. [Google Scholar]

2. Singha Mahapatra $A B$ The immune system. Essentials of Medical Physiology. 3rd ed. Kolkata: Current Book International; 2008. p. 45. [Google Scholar]

3. Sicherer SH. Epidemiology of food allergy. J Allergy

Clin

Immunol. 2011;127:594-

602. [PubMed] [Google Scholar]

4. Karl L. 2nd ed. New York: Dover Publication; 1990. The Specificity of Serological Reaction; p. 205. 330. [Google scholar]

5. Chaudhury Sujit K. Concise Medical Physiology. 6th ed. Kolkata: Central Book Agency (P) Ltd.; 2008. p. 63. Ch. 4. [Google Scholar]

$\begin{array}{lll}\text { 6. Singha Mahapatra } & A B & \text { The immune } \\ \text { system. Essentials } & \text { of } & \text { Medical }\end{array}$ Physiology. 3rd ed. Kolkata: Current Book International; 2008. p. 52. [Google Scholar]

7. Chaudhury Sujit K Concise Medical Physiology. 6th ed. Kolkata: Central Book Agency (P) Ltd.; 2008. p. 64. Ch. 4. [Google Scholar]

8. Namburi Sekhar UR Introduction to Visha. A Text Book of Agad Tantra. 1st ed. Varanasi: Chowkhamba Sanskrita Bhawan; 2006. p. 6. [Google Scholar]

9. Srikantha Murthy KR, editor. 1st ed. Varanasi: Chaukhamba Orientalia; 2002.
Sushruta Samhita of Acharya Sushruta, Kalpa Sthana; p. 423. ch. 2, Ver. 24. [Google Scholar]

10. Bhagwan D, Sharma RK, editors. 6th ed. Varanasi: Chaukhamba Sanskrit Series; 1999. Charaka Samhita of Acharya Charaka, Chikitsa Sthana; p. 326. Ch. 23, Ver. 14. [Google Scholar]

11. Namburi Sekhar UR Artificial poison (Garavisha) A Text Book of Agad Tantra. 1st ed. Varanasi: Chaukhamba Sanskrita Bhavan; 2006. p. 178. [Google scholar]

12. Bhagwan D, Sharma RK, editors. 6th ed. Varanasi: Chaukhamba Sanskrit Series; 1999. Charaka Samhita of Acharya Charaka, Chikitsa Sthana; p. 381. Ch. 23, Ver. 233. [Google Scholar]

13. T Indradev, T Dayashankar. Varanasi: Krishnadas Academy; 1998. Yoga Ratnakara, Jangama Visha Chikitsa Adhaya; p. 866. [Google Scholar]

14. Bhagwan D, Sharma RK, editors. 6th ed. Varanasi: Chaukhamba Sanskrit Series; 1999. Charaka Samhita of Acharya Charaka, Chikitsa Sthana; p. 330. Ch. 23, Ver. 24-27. [Google Scholar]

15. Sri kantha Murthy KR, editor. Ist ed. Varanasi: Krisnadas Academy; 1995. Astanga Hridayam of Acharya Vagbhata, Uttara Sthana; p. 336. Ch. 35, Ver. 49. [Google Scholar] 